\title{
Political Parties and the Rule of Law, Kosovo's Perspective
}

\author{
Luz Balaj $^{1}$, Florent Muçaj ${ }^{1}$ \\ ${ }^{1}$ Teaching Assistant, Faculty of Law, University of Prishtina, Kosovo \\ Correspondence: Florent MUÇAJ, Teaching Assistant, Faculty of Law, University of Prishtina, Kosovo.
}

Received: June 30, 2017

Accepted: July 21, $2017 \quad$ Available online: July 31,2017

doi:10.11114/ijsss.v5i8.2564

URL: https://doi.org/10.11114/ijsss.v5i8.2564

\begin{abstract}
The role of political parties in increasing the capacities for the rule of law and the internal development of political parties, are two issues among several ones discussed in this analysis. The reformation of political parties from nationwide movements in structured political parties was and remains a very little analyzed process. The developments in Kosovo and the solution of its final status have distracted the political parties from having the dedication towards many vital issues, such as rule of law, their internal reformation. In the end I have analyzed another issue which appears as an obstacle for substantial reforms of political parties, which is the lack of constitutional control for political partie s' programs and their way of functioning.

The treatment of the organization of political life, focusing on the role of political parties and their dedication for law and order, is undoubtedly a substantial and analytical innovation, important for the political parties themselves. Having a look in general scientific analysis for political parties not only within Kosovo, we can understand that studies that treat certain segments of political parties, especially their platforms, are quite late.
\end{abstract}

Keywords: Kosovo, political party, rule of law, democracy

\section{Introduction-Kosovo Case}

In the context of political parties' dedication for law and order, especially in Kosovo, it is worth mentioning the assistance that political parties received from international organizations and projects. The academic literature regarding the given assistance is new. Only from 2004 we can notice an increase of publications regarding this topic. Most of the publications are systematic explorations, basics of the issues at treatment, such as:

What is the assistance given to the parties;

Who are the main actors;

Which are the instruments of the donors;

Concepts and strategies.

However, as it was also emphasized by Peter Burnell, the practitioners of political parties' assistance and the results from the existing research for political parties and political systems. remain in two different worlds. While some political scientists with expertise in western political parties and political systems were offering advices and information about the context of the agencies for the assistance of political parties, these actions have been documented very little and the research in this topic was minimal. Our knowledge about the assistance of political parties and its effects was primarily based on ordered reports, evaluations of donor agencies and in the analysis of the researches that have collected the evaluations. The systematic research regarding the assistance for political parties has started only lately, and it uses the findings of researches for political parties in the not-western societies. In fact, some of the problems which donor agencies have been facing can be attributed to the advices that these agencies have taken from the existing researches of political science regarding political parties, from the judgmental viewpoint of Western Europe. And again, only lately, after the criticism of Thomas Carother against international assistance towards political parties as the "weakest connection", and after some paradoxically experiences and controversial results of the same kind, some agencies for the assistance of political parties have started consulting political scientists with research experience in non-European political parties, in order for them to redesign their approaches. (See for more: Political Party Research and Political Party Assistance - Gero Erdmann).

A very important and stimulating dimension for scientific work with the object of political parties, is also the 
supranational element in the organization of parties. Especially in Europe we can encounter the organization of political parties in a mutual organization which exceeds national borders. This supranational organization of political parties that have similar program orientations has enabled these scientific analyses to have greater impact and offer comprehensive alternatives. This creates the possibility of a much more serious conclusion if we treat the program and political orientation of a European political organization rather than analyzing the orientation and political program of a political subject in a national level.

The tendency of political subjects to unify their programs and political orientations inside an organization such as the European one, has created the conditions of a more unified approach towards scientific work as well. The issues related to the offer of international assistance for political parties with the research for political parties will be treated here in four parts:

The first part describes the main actors in international assistance for political parties and the problems that they face;

The second part examines the existing research regarding the assistance for political parties which remains limited;

The third and most substantial part explains the importance of political science's research, by focusing on its contribution in understanding the role of political parties in transition, from the authoritarian rule in the consolidation of democracy, while identifying a lack of knowledge in the existing researches regarding the understanding of political parties and their systems in non-western societies.

Finally, the main arguments are summarized in conclusions. While trying to explain the problems and failures of political parties' assistance, the claim is two-sided: first, the promoters of political parties have a lack of genuine political strategies, and second, they don't have adequate evaluation policies. (See for more: Political Party Research and Political Party Assistance - Gero Erdmann).

\section{The Organization and Programs of Political Parties in Kosovo until the Declaration of Independence}

The organization of political parties in Kosovo can be genuinely treated regarding the program aspects only in the period after communism. This is because in this period, the first elements of pluralism and different programs of political parties begin to appear. The reflection of the political condition in Kosovo and the lack of a final solution for Kosovo's status was one of the main factors that have impacted the programs of political parties. The reflection of political parties in Kosovo within this analysis will not stop for long in the period during the 90 's and the dominance of the Democratic Union of Kosovo (LDK) as a peaceful resistance, while it will treat the post-war period (1999) and the organization of political life, the building of programs and actual political offers. (See also: The integration of Kosovo's political parties in international organizations of political parties: The explanation of the delay - KIPRED, May 2015).

In order to clearly identify the programs of Kosovar political subjects, in the context of coherence and dedication in conformity with society's problems, we will give a point of view regarding what in fact should we understand as an election program. 'The election program has been drafted with special solutions and may contain proposals and requests regarding future activities which may be de veloped by a party after the formation or merger in the government. Election programs have to be written before the elections. Normally, they are written in close contact with the main candidates of a party, who then are responsible for putting their political views in front of the public. In many countries, many parties do not take that much effort in developing a party program and give it little attention, because they are mainly identified by their representatives rather than by their programs. However, they should not underestimate the role of a comprehensive program for the profile and identification of its members with the party. The program of the party unfolds the main views of the party in front of the members and representatives of the party, as well as in front of the citizens, and this testifies whether a party can translate social problems into political suggestions and programs. Therefore, every party should give greater importance to drafting a coherent program. Furthermore, the discussion for the program of a party has to be done in a longer period of time, with the intention of updating the program of the party, thus offering the opportunity to lead program debates within the party and with other social groups. (See for more: Political parties, their functioning and organization in democratic societies - Wilhelm Holfmeister and Karsten Grabow, Konrad Adenauer Shtiftung).

In front of such a point of view, the participation in the institutional life along with the international presence and the limited approach in decision-making has been a challenge on its own for political parties. This is because of the fact that the implementation of political parties' platforms in Kosovo has been a tough process of consultation with international institutions.

An interesting fact that unfolds the real condition of political parties' programs in the post-war period is definitely the final status of Kosovo. The engagement of all political parties to present their vision for the solution of the final status through their electoral programs was huge. However, we also have to treat the lack of any concrete proposal about which will be the mechanisms or steps that political subjects have in disposition to realize the solution of the final status, 
as well as a new reality, which will be the platform for the rule of law?

In this context, there appears to be a mutual denominator for the political programs of political parties after the war. This is the lack of courage to predict a period of time until which these subjects will realize their programs, in conformity with this issue. (See for more: the programs of political parties, LDK-PDK, for the national election of the year 2001).

During this period, sensitive spheres as the rule of law, continued to be under the platform of the international presence. This means that any strategy of local political parties that had the aim to be transformed in a legislative strategy was impossible, because of the fact that Kosovo's political status was yet undefined. The governance of Kosovo with the Constitutional Framework meant the inability of the interim self-governing institutions to exercise the competences in the field of rule of law, in an independent manner. (See also: The Constitutional Framework - Chapter 5 - The responsibilities of the interim self-governing institutions).

This undoubtedly was reflected in the programs of political parties in the elections held before the declaration of independence, because in the period of 1999-2007, the orientation of political parties for the rule of law was faded. The existence of this prerogative within the competences of the Special Rapporteur, according to the Constitutional Framework, has made political parties reserved in offering their alternatives regarding law and order. (See for more: programs of the parties LDK, PDK, AAK) By analyzing the programs of these parties during the national elections of the period 1999-2007, it is noticed that regarding the dedication of these parties there is unification in their objectives for justice. This can be easily understood, since the country was undergoing the transition period. The objectives displayed by political parties as goals within their platforms are very general.

The most predominant ones are: a) the independence of the judicial system, which subjects connect with a more consolidated budget and decent salaries for the judges; b) reform in the judicial system, was also an issue which appeared in the platforms of all political parties; c) the consolidation of organs in the judicial sector, managing organs such as the Judicial Council or the Prosecutorial one, were also part of political platforms; d) with some exceptions, some subjects, such as LDK, within the electoral platform related to justice also gives attention to the professional and adequate education of judges by offering guarantees for the increase of the efficiency of the judicial system as a result of a more qualitative preparation.

If we generally analyze the entire perspective of justice from the political parties program's point of view during this period, we can easily understand that we are dealing with a society going through transition. The most valuable argument can be found in political offers, which give promises for the consolidation of managing organs in the sector of justice. (See for more: political parties programs, national elections of the year 2007) Concretely, the platforms of political parties include their engagement that in addition to their dedication for law and order, will work with dedication in the creation of the Judicial Council and the Prosecutorial Council.

Knowing that political parties in democracy want to earn votes, it can be noticed that political programs nowadays are a result of other developments that are related to the international presence in Kosovo. (See: Political Parties and Uncertainty in Developing Democracies Noam Lupu1 and Rachel Beatty Riedl).

This means that these political programs in rapport with the rule of law and the creation of an advanced system of law, have serious lack of their vision. This is shown in the fact that political subjects have predicted and pretended similar political actions within one electoral mandate. By pretending the concretization of their actions and steps with the same epilogue as the creation of managing bodies in the justice sector, also shows that these parties have been waiting the overall political developments that have been mainly determined by the agenda of the international presence in Kosovo. In this context, in many cases political parties have been accused by civil society precisely because of the fact that in their electoral programs, there has been protocol agenda. What does this mean? This means that the difference between political programs regarding the rule of law has been minimal. Dictated by the needs that showed up during the process of transition, political subjects in most of the cases have been justified with the fact that the lack of their space for decision-making has derived from the Constitutional Framework as well as the lack of a new law for the organization of the judicial system. The presence of international judges and the role of the Special Rapporteur of the Secretary-General have been relevant challenges, through which political parties have been justified with the lack of space to offer a comprehensive alternative. "The judges and prosecutors are appointed by PSSP, from the lists of candidates proposed by the Judicial and Prosecutorial Council of Kosovo and approved by the Parliament. The decisions for the advancement, transfer or dismissal of judges and prosecutors are taken by PSSP based on the recommendation of the Judicial and Prosecutorial Council of Kosovo, and in special cases by their own initiative." (See for more: the Constitutional Framework for Interim Self-Governance, Chapter 9 part 4, paragraph 7 and 8). 


\section{Program Orientation of Kosovo's Political Parties Regarding Law and Order, after the Declaration of Independence}

The creation of a coalition, seen as galvanic by many political scientists, is the coalition between two of the largest parties from the elections of 2007 - PDK and LDK, created a new political moment, which in first sight seemed to return Kosovo in the time of the interim mutual governance of a broad coalition. Big defects would come up in any tendency to make an analysis for the orientation of this coalition's program, because the orientations of these two parties had enormous essential differences in many spheres.

The implementation of the political program of this coalition and its transformation in a legislative agenda presents the best moment for a genuine analysis of its political orientation. But, the agendas set in cooperation with the international community for the declaration of independence left other aspects of the program in shadow. (See for more: Political parties, their functioning and organization in democratic societies - Wilhelm Holfmeiste \& Karsten Grbow, Konrad Adenauer Shtiftung, Pristina 2013) Therefore, this coalition couldn't clearly transform its pre-election program in a genuine legislative agenda. This happened because the list of laws that had to be approved in the Parliament after the declaration of independence were dictated by state-building needs, and not by the programs and political goals of the political parties in coalition. In this context, this coalition was obliged to prioritize the approvement of laws which enabled the functionality of state institutions. This reasoned the avoidance of this coalition from the implementation of its pre-election programs. Of course we have to mention that, in one manner, the declaration of independence itself was part of these parties program in the 2007 elections. (For more, see pre-election programs of political parties in the 2007 elections: PDK, $L D K, A A K$.

As for the law and order, this coalition which governed until the end of 2010, has passed a number of laws which set a new standard, now constitutional. One of the main changes regarding law and order is definitely the approval of the law of courts. (See for more: The Law of Courts Nr. 03/L-199). This law, which was approved in 2010, during the governance of this coalition, has brought a new scheme for the organization of the judiciary.

This law was a result of a long work of local and international experts and it has been approved and signed in July 2010.

Another change which is indirectly related to law and order is undoubtedly the creation of the Constitutional Court. This is because of the fact that the guarantee of human rights and freedoms, gains another level of protection against any possible violation by public authorities. (See: The Constitution of the Republic of Kosovo, Article 113 and the Law of the Constitutional Court No. 2008/03-L-121)

All these changes in different segments of justice and rule of law which have been identified in this paper, but also many other reformation processes that have had less impact in the rule of law could not be identified as priorities in the programs of the political parties in coalition. The most real reasoning for the lack of a platform to be implemented by the government of that time is the dynamic of developments itself in the post-independence period. This dynamic has not spared the justice and other changes either regarding law and order, by not giving it attention within the platforms of political parties.

\section{Political Parties as Promoters of the Rule of Law and Democratic Order}

The biggest indicators to understand the engagement of political subjects to create a secure environment and respect for law and order, are the reform developments inside political parties themselves.

By interconnecting with the first part of the paper, where we talk about the involvement of political parties in the families of European parties, we have to keep in mind that it is exactly the lack of inclusion in such political organizations that has brought stagnation in the processes of political parties' internal reforms, which did not have a general standard to identify as a level of achieving reforms.

The analysis of the Statutes of the largest political parties in the country can give us some arguments which more precisely show the level and magnitude of reforms in these subjects.

The Democratic Party of Kosovo (PDK), which has approved its Statute in June 2000, has had a low rhythm of reforms. Which is the argument that allows this conclusion for the low rhythm of reforms? This conclusion is allowed by analyzing the reforms of model parties, as is for example the Labor Party in England which has set internal leadership elections in case of loss in elections. The political parties in Kosovo, in this case PDK, was not able to engage itself in such level of reforms. A lack of such responsibility can be considered as a lack of readiness for reforms. This is because of the fact that the parties have not set the responsibilities for their leader, have emphasized problems with the internal democracy and the role or authority of the Head of the party. Regarding the rule of law, the reforms within the party during the years 2002, 2005 and 2012, PDK did not have many changes in its platform about which will be its vision for the rule of law and democratic order. (See for more: the Statute of the Democratic Party of Kosovo, approved in 2000). 
The Democratic Union of Kosovo (LDK), being a party with an older tradition, has had a more complex process of reforms. In its internal organization, the party has preserved some conservative elements, by not creating an internal normative infrastructure which would place the responsibility of leaders in a disputable position in the case of loss in elections. The Statute of LDK in the genesis of its organization has regulated the activity of LDK in the capacities of a popular movement. Therefore, we can say that the reforms in LDK are connected to two moments: first, the reforms which brought its re-organization from a popular movement in a structured political party; second, the reform processes as a result of its acceptance in the European family, concretely in the group of the European popular parties. In conformity with the rule of law and the creation of a democratic order, LDK has been followed by a slow process of reforms. (See for more: the Statute of the Democratic Union of Kosovo - LDK).

Lëvizja Vetëvendosje is one of the newest political subjects, but which has been included in a more dynamic process of internal reforms. As a result of this intensive process of reforms, Lëvizja Vetëvendosje which has approved its Statute in 2008, has set a more democratic level that reflects its internal organization. From a comparative point of view within political subjects, concretely their statutes, we can notice that LVV is a step forward from its partners, especially in rapport with the internal elections, because in its statute it is concretely emphasized: Article 10, point 1 - The mandate for every leading and delegated position of LVV, in its three organizational levels, is three years. This Article definitely makes LVV a more reformed subject regarding the standard of elections, since from the analysis of the statutes of other parties, there is no such obligation for any leading level. (See for more: the Statute of Lëvizja Vetëvendosje, approved in 2008).

By generally evaluating the engagement of political subjects to promote the rule of law and the creation of a democratic order, we can notice some discrepancies between internal reforms, especially the election one and their own engagement for general reforms in the society. In this context, we can see that the lack of a legal filter for the statutes of political parties has created the space for these subjects to undertake reforms which are not that substantial.

In many democratic countries, the statutes of political parties are subject to a control, even if it is a constitutional one. This is done to ensure that the purpose of these subjects, expressed through their statute but also through its concrete political activity, does not violate the Constitution and constitutional values of a certain society. Currently, with the Constitution of Kosovo, the Constitutional Court of Kosovo does not explicitly have such a prerogative. Therefore, this can be an another reason that justifies the level of reforms of the political parties in Kosovo, having in mind the three largest parties, included in this paper: the Democratic Party of Kosovo, the Democratic Union of Kosovo and Lëvizja Vetëvendosje.

\section{Conclusion}

The paper: Political parties and the rule of law, Kosovo's perspective - treats general aspects of developments of the political scene in Kosovo, by emphasizing the political engagement for the creation of a democratic order and rule of law. The paper initially brings up the fact that the organization of political parties and their dedication for the rule of law is a very little analyzed segment. The lack of research for political parties in special segments was also noticed by foreign authors, quoted in this paper. According to the analysis, the first changes in this direction are encountered when political parties start to become members of international political unions and in supranational political organizations.

Further, the paper compares separately the engagements of the main political subjects in Kosovo for the rule of law, in the period before the declaration of independence and after it.

This paper finds that there has been a dictation of political agendas regarding the rule of law, which appear for a number of reasons. In the period before the declaration of independence, these agendas were dominated by the need to concentrate in the solution of the final status. While the period after the declaration of independence, has brought a legislative agenda, which aimed the building of the state, by thus avoiding a full implementation of political platforms. This happened as a result of the Parliament's focus in a dynamic issuing of laws that enabled the vital functioning of the state of Kosovo.

The paper emphasized important developments regarding the rule of law and democratic order. On the other hand, it also shows a lack of a causal connection between these developments and political platforms, because most of the changes that have accompanied the system of justice in Kosovo are unavoidable processes for the functionality of the state. Thus, they are not preliminary objectives of political parties, presented in an electoral platform.

In the end of the paper, there is also an analysis for the internal democracy of some political subjects as a reflection of a new reality in the sphere of the rule of law, by also analyzing the role of the leader, as the main element in the internal democracy. In this direction, the paper shows the obstacles during the process of internal reforms in political parties. As a consequence, political parties were disables to have an active role as promoters for the rule of law, because their own internal democracy until now has been very fragile. There are a lot of reasons for this, but one of them, treated in this 
paper, is definitely the fact that in Kosovo political parties are not subject to constitutional control regarding their stat ute and activities. This can be a starting point in understanding the lack of reforms within the parties themselves, and definitely the lack of political parties' dedication for positive changes in the rule of law sphere.

\section{References}

GIGA German Institute of Global and Area Studies - Legitimacy and Efficiency of Political Systems Lessons to Be Learned: Political Party Research and Political Party Assistance - Gero Erdmann - No. 149, October 2010.

The election program, LDK, National Elections of 2001.

The election program, PDK, National Elections of 2001.

The election program, LDK, National Elections of 2007.

The election program, PDK, National Elections of 2007.

The election program, AAK, National Elections of 2007.

The Statute of the Democratic Union of Kosovo (LDK).

The Statute of the Democratic Party of Kosovo (PDK).

The Statute of Lëvizja Vetëvendosje (LVV).

Political Parties and Uncertainty in Developing Democracies Noam Lupu1 and Rachel Beatty Riedl.

Political Party Research and Political Party Assistance - Gero Erdmann.

The integration of Kosovo's political parties in international organizations of political parties: The explanation of the delay - KIPRED, May 2015.

Political parties, their functioning and organization in democratic societies - Wilhelm Holfmeister and Karsten Grabow, Konrad Adenauer Shtiftung, 2013.

The Constitutional Framework of Kosovo for Interim Self-Governance.

The Constitution of the Republic of Kosovo.

The Law of the Constitutional Court, Law No. 2008/03-L-121.

The Law of Courts, Law No. 03/L-199.

\section{Copyrights}

Copyright for this article is retained by the author(s), with first publication rights granted to the journal.

This is an open-access article distributed under the terms and conditions of the Creative Commons Attribution license which permits unrestricted use, distribution, and reproduction in any medium, provided the original work is properly cited. 